\title{
Retranslation and Counterculture in Post-Francoist and Modern- day Spain: Woody Guthrie's Bound for Glory in Star Books (1977) and Global Rhythm Press (2009)
}

\author{
Camino Gutiérrez Lanza \\ Universidad de León \\ mcgut1@unileon.es
}

Resumen: El activista político y prolífico artista Woody Guthrie (1912-1967) es conocido a nivel internacional como una de las figuras más representativas de la música folk norteamericana. Su autobiografía Bound for Glory, publicada por primera vez por E.P. Dutton en 1943, es un perspicaz relato de los años de la Gran Depresión y de los viajes subsiguientes. Star Books la publicó por primera vez en España en 1977 y en 2009 lo hizo Global Rhythm Press. Este artículo estudia el relevante papel sociocultural que ambas editoriales han desempeñado en la España posfranquista y en la época actual, cómo el texto ha sido (re)traducido y si la segunda traducción ha modernizado a la primera para colmar las expectativas de los lectores contemporáneos.

Palabras clave: retraducción; contracultura; posfranquismo; Woody Guthrie; autobiografía.

Abstract: Political activist and prolific artist Woody Guthrie (1912-1967) is internationally renowned for being one of the most representative figures of American folk music. His autobiography Bound for Glory, first published by E.P. Dutton in 1943, is a vivid account of the Great Depression years and the travels that followed. It was first published in Spain by Star Books in 1977 and later by Global Rhythm Press in 2009. This paper explores the relevant socio-cultural role played by both publishing houses in post-Francoist and modern-day Spain, and looks at the way the text has been (re)translated, assessing whether the second translation modernised the first in order to fulfil the expectations of contemporary readers.

Keywords: retranslation; counterculture; post-Francoism; Woody Guthrie; autobiography.

》) Gutiérrez Lanza, Camino. 2015. "Retranslation and Counterculture in Post-Francoist and Modern-day Spain: Woody Guthrie's Bound for Glory in Star Books (1977) and Global Rhythm Press (2009)". Quaderns de Filologia: Estudis Literaris XX: 125-144. doi: 10.7203/qdfed.20.7533 



\section{Introduction}

This paper sets out to provide an analysis of translation and censorship practices in post-Francoist and modern-day Spain by examining the trajectory in our country of one of the most celebrated autobiographies of the American counterculture: Woody Guthrie's Bound for Glory. ${ }^{1}$

Bound for Glory, originally published in 1943, was among the books that were never translated into Spanish during the Francoist period (1939-1975). It was soon after Franco's death, in March 1977, that the first Spanish translation was submitted to voluntary consultation in Spain, following the official procedure. The book received the necessary authorization and was published by Star Books that year. In addition to the 1977 publication, and probably as a consequence of the recent worldwide revival of the figure of Woody Guthrie, Bound for Glory was retranslated and published in Spain in 2009 by Global Rhythm Press.

In the following sections we will begin by examining the reasons why Woody Guthrie was and still is such a relevant figure and why his autobiography remains so valid in the world of today, which to a large extent explains why it has been chosen here as the object of study. After that, through a combination of approaches, including text-linguistic (Beaugrande \& Dressler, 1981; Neubert \& Shreve, 1992), descriptivecomparative (Toury, [1995] 2012), functional (Nord, 1997), as well as macro- and micro- (Tymoczko, 2002) approaches, we will identify and examine the main highlights of Guthrie's autobiography Bound for Glory and its Spanish translations. This examination will focus mainly on those (para)textual issues which were traditionally considered problematic by Francoist censors. The comparative analysis of the source text in English and its two Spanish translations will reveal whether certain problematic passages still suffered the effects of post-Francoist censorship in the 1977 translation and, if they did, whether those passages were restored in the 2009 translation.

\footnotetext{
${ }^{1}$ Research for this paper has been undertaken as part of the TRACE project (Traducción $y$ Censura / Translation and Censorship), funded by the Spanish Ministry of Economy and Competitiveness (FFI2012-39012-C04-03). More information on line at: http:// trace.unileon.es.
} 


\section{Woody Guthrie, his contemporaries, and his followers}

Woodrow Wilson "Woody" Guthrie was born in 1912 in Okemah, a small town in Oklahoma which enjoyed unusual prosperity before the First World War "because it blossomed out into one of our first Oil Boom Towns" (Marsh \& Leventhal, 1992: 3). After a not so happy childhood selling newspapers and singing traditional songs, Guthrie spent most of the 1930s travelling around Oklahoma, Texas and California. In those years, the Great Depression forced whole families to flee to the West, leaving their homes to the mercy of terrible dust storms (Van Doren \& McHenry, 1971: 455):

In the spring of 1934, the farms of the Dust Bowl - which includes western Oklahoma, western Kansas, eastern Colorado, the panhandle of Texas, and parts of Wyoming - blew clear out to the Atlantic Ocean, 2,000 miles away. On a single day 300 million tons of rich top soil was lifted from the Great Plains, never to return, and planted in places where it would spread the maximum of damage and discomfort. Authentic desert sand dunes were laid down. People began to die of dust pneumonia. More than 9 million acres of good land has been virtually destroyed by wind erosion, and serious damage is reported on nearly 80 million acres.

Guitar in hand, Guthrie headed towards California riding on freight trains, singing in saloons, and watching everyone he met along the way. The essence of his personality is reflected in the following words (Shelton, 1987: 76):

Woody Guthrie was the archetypal American troubadour, a singer, taleteller, poet, prophet-singer, roustabout, organizer, union man, traveller, journalist, peach-picker, hitch-hiker, rambler, migrant worker, refugee. He was a footloose rebel, a very early dropout.

As can be seen in his numerous drawings and writings (Marsh \& Leventhal, 1992), Guthrie was an insatiable reader. In his diaries there are quotes from Lee Hays, Lenin, Aunt Molly Jackson and Lead Belly, to name only a few, which show the political and musical influences of his production. His songs found their roots in American traditional music. In general, they borrowed their melodies from other songs which he 
had mostly learnt from his mother, with such annotations in his manuscripts as "This goes good to the tune of Blue Eyes with a little of Wildwood Flower mixed in" (Greenway, 1953). Moreover, most of them turned into classics of the American folk tradition, with titles such as This Land is your Land, Pastures of Plenty, So Long, it's Been Good to Know Yuh, Union Maid, Dust Bowl Refugee, some other Dust Bowl Ballads and many other ballads and talking blues.

No doubt, "like Steinbeck's Tom Joad, the hero of Grapes of Wrath, Guthrie was of the uprooted, disenfranchised, impoverished migrants" (Shelton, 1987: 77). He joined organised movements in favour of workers and his protest songs were listened to all over the United States. He symbolises human independence, sympathy for the disadvantaged, the joy of happy gatherings to the sound of music, and the defence of justice, which made him protect refugees against landowners with words such as the following (Shelton, 1987: 76):

I hate a song that makes you think that you're not any good. I hate a song that makes you think that you are just born to lose. Bound to lose. No good to nobody.

Guthrie died of Huntington's disease on 3 October 1967. "Within an hour, the wire services were carrying news of his death and it was all over the radio - along with musical tributes on many stations" (Klein, [1980] 1998: 444). His footsteps have been followed by contemporary musicians such as Cisco Houston, Pete Seeger, and Lead Belly, by leading artists such as Bob Dylan and Bruce Springsteen, whose career started under his influence (Fernández Ferrer, 2007), and more recently by alternative musicians of younger generations such as Billy Bragg and Wilco, whose album Mermaid Avenue (1998) is a compilation of previously unreleased lyrics written by Guthrie. Many of them consider Guthrie "a legend" (Scaduto, 1973: 39), and one of the main predecessors of the American folk revival of the late fifties and early sixties, "introducing and popularizing rural, roots, topical, and protest music to modern urban audiences" (Woody Guthrie Publications, Inc., 20012015). In fact, both Fernández Ferrer (2007) and folksinger Joan Baez (Anon, 2014) acknowledge that American folk music of this period was part of a countercultural movement that looked back on Guthrie as a source of inspiration. 
Together with the Woody Guthrie Center, "dedicated to celebrating Woody's life and legacy and educating a new generation about his important role in American history" (Woody Guthrie Center, 20132015), the Woody Guthrie Folk Festival (Woody Guthrie Folk Festival, 2013), and websites such as The Official Woody Guthrie Website (Woody Guthrie Publications, Inc., 2001-2015) and Guthrie Green (Guthrie Green, 2014), his followers have brought his socio-political and cultural legacy forward to the present. Indeed, he has been described as "an Okie Walt Whitman, carrying his song of the open road down a modern highway" (Shelton, 1987: 74). Furthermore, after the one-hundredth anniversary of his birth, celebrated on 14 July 2012, there has been a large-scale revival of Guthrie's figure. This new peak of world-wide popularity was followed in 2013 by the publication by Harper of his long-lost novel House of Earth, written in 1947 and rescued and introduced by actor Johnny Depp. Jesús Zulaika's translation into Spanish, published by Anagrama in 2014 with the title Una casa de tierra, has recently brought Guthrie to the forefront in Spanish newspapers with a significant number of positive reviews.

\section{Bound for Glory and its Spanish translations}

\subsection{Bound for Glory (E.P. Dutton, 1943)}

In 1943 Woody's name appeared on the cover of a book whose publishers, E.P. Dutton and Company, described it as "perhaps the strongest picture yet written of America's will to win" (Greenway, 1953: 279). Bound for Glory is an uncomfortable book for the reader, a work of deep social satire which depicts the poor moral values of big landowners and people's illusions being turned into dust.

He managed to capture varied literary influences from among his fellow countrymen. Just as Mark Twain and James Fenimore Cooper before him, Guthrie developed the romantic idea of human innocence versus social experience. He "was compounded of equal parts of Whitman, Sandburg, Will Rogers, and Jimmie Rodgers" (Shelton, 1987: 74). Special attention must also be paid to a book which deserved the Pulitzer Prize in 1940, The Grapes of Wrath by John Steinbeck, whose protagonist inspired one of Guthrie's most remarkable songs, Tom Joad. Greenway (1953: 289) reveals what Guthrie himself said about the song: 
I wrote this song because the people back in Oklahoma haven't got two bucks to buy the book, or even thirty-five cents to see the movie, but the song will get back to them $[\ldots]$.

Bound for Glory, with 320 pages in the Picador edition, was "rapturously received" (Shelton, 1987: 78) by American critics and enjoyed great repercussion in musical circles. Guthrie's literary and musical example was soon celebrated by other writers and musicians such as Kerouac with On the Road, published in 1955, and Bob Dylan, who "swallowed Woody's early autobiography [...] as if he had discovered the Bible" (Shelton, 1987: 74). Apparently, David Whittaker told Dylan he had to read the book "as they listened to Woody's Dust Bowl Ballads" (Scaduto, 1973: 39) and it came "as a real shock. For the next two years he patterned his life after what he had read. Bob started doing everything the way Guthrie did" (Shelton, 1987: 75). Dylan also reflected his passion for Guthrie in his work, describing him in one of his 11 Outlined Epitaphs, paying homage to him in the long and rambling Last Thoughts on Woody Guthrie and in Song to Woody (Dylan, 1984), and playing Guthrie's Tom Joad "after reading the book Bound for Glory and he'd play it all day long, that half-hour song. All day long. Day after day" (Scaduto, 1973: 40).

Bound for Glory describes the way Guthrie leaves dusty Oklahoma in search of the green promise of California due to the devastating dust storms that ruined his homeland during the 1930s. It contains rich and varied references to American geography and culture, and there are frequent allusions to two land-based transport systems which were, and still are, used to move around the vast geography of the country: the long highways -symbols of the long exodus and fruitful source of inspiration for countless American writers and artists; and the railroad, dating back from the times when western territories were being colonised. What is commonly known as white line fever, the need for travelling, this time in search for something better, also appears in the book, which is also full of references to the two most important sources of energy at the time, coal and oil, the last of which was responsible for the black gold rush which would make many people rich much too quickly, only to leave them in poverty shortly afterwards.

Guthrie's style is so direct that communication with the reader is established in a highly effective way. Discourse alternates between nar- 
ration and dialogue. The narrative is more elaborated but retains most of the colloquial style of the author: "We got off to a jumpy start while he was spitting out his windows", "the early green wheat that pushes up just in time to kiss this March wind", "sun so clear and so bright that I felt like I was leaving one of the prettiest and ugliest spots I'd ever seen". The dialogue is full of simple sentences, elliptic syntax, coordination, fillers, and rare examples of subordination. Subjects and even verbs are often absent ("jumped up big", "oil derricks running up", "silvery refineries", "where ya headin'?", "sun so clear") and distorted morphology is used to transcribe speech into writing with no established conventions: "outta", "enda", "ain’tcha", "a-likin' th' looks", "daun ta", "ta th' north" (Guthrie, [1943] 1977: 188-227). Regarding Guthrie's use of language in Bound for Glory, Greenway (1953: 287) says:

He is a logophile [...]. [...] the curious associations which he finds between simple terms lead him into fantastic flights of imagery. Metrical restrictions fetter these flights in his songs, but in his prose they are completely unrestrained. [...] His diction is filled with picturesque expressions which we, who can merely write grammatical correctness, may envy.

Both as the main character and the narrator of the story, Woody experiences great personal development and changing relationships with the world as he witnesses people suffering. Group differences are stressed by the sociolinguistic features of their speech. Their informal -and sometimes even colloquial- personal tenor highlights the variety, colour, and richness of America. Far from depriving the different characters of their dignity, dialectal varieties -also used by significant writers such as Twain or Steinbeck-, restricted codes, peculiar rhythm, elliptic syntax, and distorted morphology contribute to provide a more authentic portrait of society.

Due to its remarkable success, Bound for Glory inspired an eponymous film directed by Hal Ashby in 1976, featuring David Carradine in a brilliant interpretation of Woody's adventures and his inimitable style with the guitar. We presume that it was partially due to Carradine's great popularity in our country with the TV series Kung Fu (1972-1975) that the film was released in Spanish cinemas in 1978 with the title Esta tierra es mi tierra, which is the Spanish translation of Guthrie's famous song title This land is my land. Nowadays Esta tierra es mi tierra is 
being distributed in Spain in DVD by Twentieth Century Fox Home Entertainment (Ashby \& Getchell, 1976).

\subsection{Con destino a la gloria (Star Books, 1977)}

According to the documents found in the unpublished file 3503-77 (Dirección General de Cultura Popular, 1977), nobody tried to publish Bound for Glory during the Franco dictatorship in Spain (1939-1975), presumably due to the political beliefs of its author. It is therefore not surprising that soon after Franco's death, and more than 30 years after the book's publication in the United States, Manuel González Martínez, in representation of Producciones Editoriales S.A. publishing house, Star Books series, submitted the book to voluntary consultation on 15 March 1977, with the title Con destino a la gloria, declaring it to have 474 pages and an intended circulation of 9,000 copies. One day later, on 16 March 1977, reader 12, who remains anonymous, issued the following report which, due to its significant historical value, is reproduced in full:

Novela autobiográfica en la que el autor, cantante de música folk, relata su vida. Nacido en una familia feliz que una serie de adversidades arruina y separa, el autor se va empujado a una vida difícil de peregrinaje en busca de trabajo en una época de depresión económica pero que será el origen de su vocación de cantante del pueblo con el que se ha identificado.

El autor quiere denunciar en esta obra a la sociedad americana que bajo una apariencia brillante de prosperidad encierra también un mundo de pobreza y desesperanza. La crítica está hecha sin amargura y sin agresividad. El autor más que atacar quiere poner de manifiesto una situación y dar a conocer el mundo de los marginados.

No impugnable.

As we have found from our own experience, this report follows what came to be the usual pattern up until 1985 (when this type of report finally stopped being produced): controversial books were approved by the authorities quite often on the grounds that wrong moral attitudes were either foreign to our country or were somehow punished in the overall development of the story. As can be read in this report, since the author denounced some particular vices of the American society 
(implying they were alien to Spanish habits), Con destino a la gloria, translated by Lisa Garrigues and Alberto Estival, was authorised for publication in 1977 for the first time in Spain, and with no amendments whatsoever to the proposed translation.

It is no wonder that Star Books, directed by Jaime Rosal and Juan José Fernández, was responsible for putting out this publication. The same publishers behind Star Books were also behind the magazine Star which was started in 1974. Created while Franco was still alive, in a country where culture had been tightly controlled by censorship for decades, Star was the primary representative of the post-Francoist counterculture in Barcelona (Fernández, 2007). Its pages were the best chronicle of this key historical period (Rivas, 2007; Gonzalo, 2009, 2011, 2014), ranging from the most subversive underground comics to the most controversial books and the most innovative records. All of a sudden, after so many years of silence, many marginal authors such as Robert Crumb, Robert Shelton, the authors of the Beat Generation (Kerouac, Ginsberg, Burroughs, etc.), Woody Guthrie, and Jim Carroll, among others, started to be translated and published in Spain (Castillo, 2014).

Star stopped being published in April 1980, and the Star Books collection was discontinued shortly after. Cultural initiative moved from Barcelona to Madrid and many of its regular contributors either succeeded in other media in the 1980s or tried their luck in other cultural projects (Manrique, 2008). However, its innovative spirit brought a breath of fresh air to the people of a whole generation.

\subsection{Rumbo a la gloria (Global Rhythm Press, 2009)}

In 2009, more than 30 years after its first translation into Spanish and more than 60 years after it had been published in the United States, Bound for Glory was retranslated by Ezequiel Martínez and published by Global Rhythm Press with the title Rumbo a la gloria. According to the information available on their web page (Global Rhythm, 2011), this publishing house is "distinguished by a diabolic reputation" and "the most extensive, intensive, and heterogeneous catalogue of books devoted to all areas of musical or paramusical activity", such as biographies and memoires, histories of musical trends and movements, cultural essays on albums, record companies or songs, as well as interviews with artists. In terms of their target audience, they speak to both Spain 
and Latin America, and mention the availability of materials online. They intend to expand the catalogue, and consolidate their position in what they deem to be "uncertain territory," what in modern-day Spain could probably be called "modern counterculture". Consequently, they seem to be succeeding in their ambition to keep presenting modern readers with those books which would not reach their hands otherwise.

The series, Memorias, aims both at rescuing certain authors from oblivion and at rescuing authors' own memories in the form of autobiographies, interviews, and testimonies (Global Rhythm, 2011):

Puede decirse (con miedo a exagerar) que hemos cultivado un vergel antes yermo en España y en América Latina llevando a la imprenta obras decisivas para la comprensión de la música contemporánea, y lo hemos hecho en dos direcciones básicas: la recuperación de trabajos incomprensiblemente preteridos en nuestro idioma (Ellington, Gould, Guthrie, Dylan) y la adquisición de novedades tan estrepitosas como las autobiografías de Art Pepper y Count Basie o las esperadas memorias de Keith Richards.

The front cover of 365-paged Rumbo a la gloria is an example of this. While Star Books showed an endless railroad track getting lost in the horizon, its peculiar Star Books logo on the top left-hand corner, the name of the author, and the title of the book in big letters, Con destino a la gloria, Global Rhythm seems to be sending a different message: from top to bottom it announces the prologue by well-known folk musician Pete Seeger, the title Rumbo a la Gloria, the name of the author in big font size, the name of the series, and finally, occupying two thirds of the front cover, it includes one of the most famous photographs of Guthrie holding his guitar with the legendary inscription "This machine kills fascists". In addition, in order for readers to become more familiar with Guthrie's legacy, the CD Bound for Glory: The Songs and Story of Woody Guthrie Told by Will Geer has been attached at the end of the book, and long and informative reviews by The Nation, John Steinbeck, and Bob Dylan have been incorporated on the back cover.

\section{The translation of traditionally problematic areas}

In addition to the obvious changes in the external appearance of both translations, we are also interested in revealing whether or not the key 
problematic areas of the source text were censored in either of the two Spanish translations. Since the Francoist censorship system was still active at the time the first translation was published, the descriptive-comparative analysis in this section will show whether or not the problematic passages of the source text were censored in the 1977 translation and, if they were, whether or not they have been restored in the 2009 translation. Our descriptive-comparative analysis will focus on those textual areas which specialists (Abellán, 1980; Gómez Castro, 2008) have traditionally considered to be the most problematic for Francoist book censors, as any affront in these areas was thought to go against the basic principles of the regime. These problematic areas include: sexual morals, religion, political beliefs, and the use of indecorous language.

\subsection{Sexual morals and religion}

Given the way the plot of the book is developed, offensive references to sexual morals and religion are not frequent in Bound for Glory. However, there is one particular passage in which Guthrie, "in the wonderful, dangerous way that children and naïs have" (Klein, [1980] 1998: 133), includes an anecdote about how he spent his time as a child. One day, while he was playing with the kid next door, both of them trying to open "a big fruit jar of peaches" (Guthrie, [1943] 1977: 44) which finally broke into a thousand pieces, they had an innocent conversation that went like this:

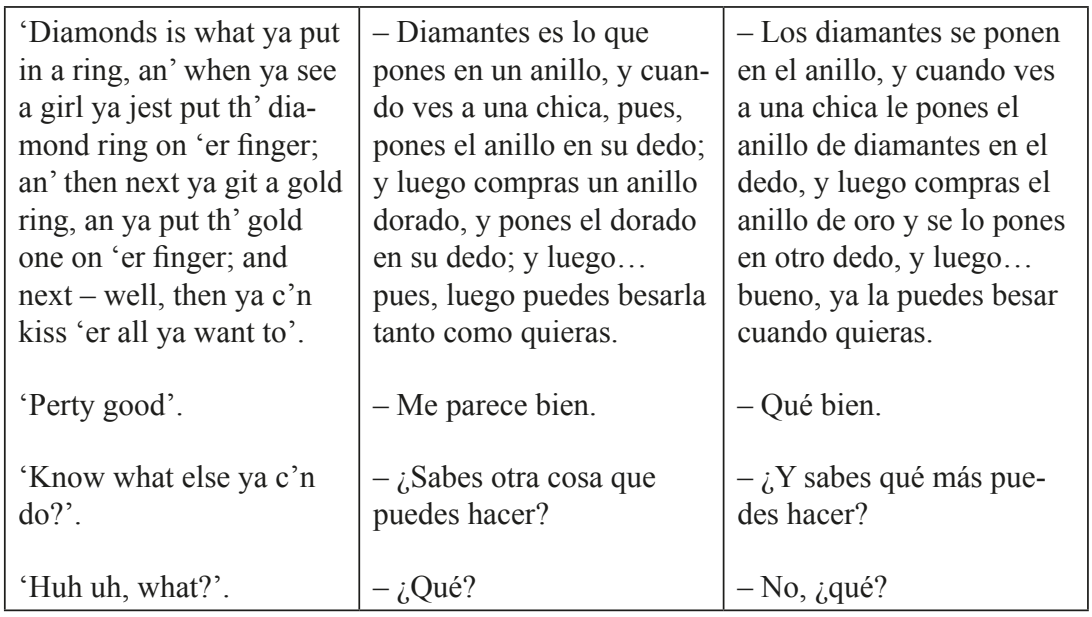




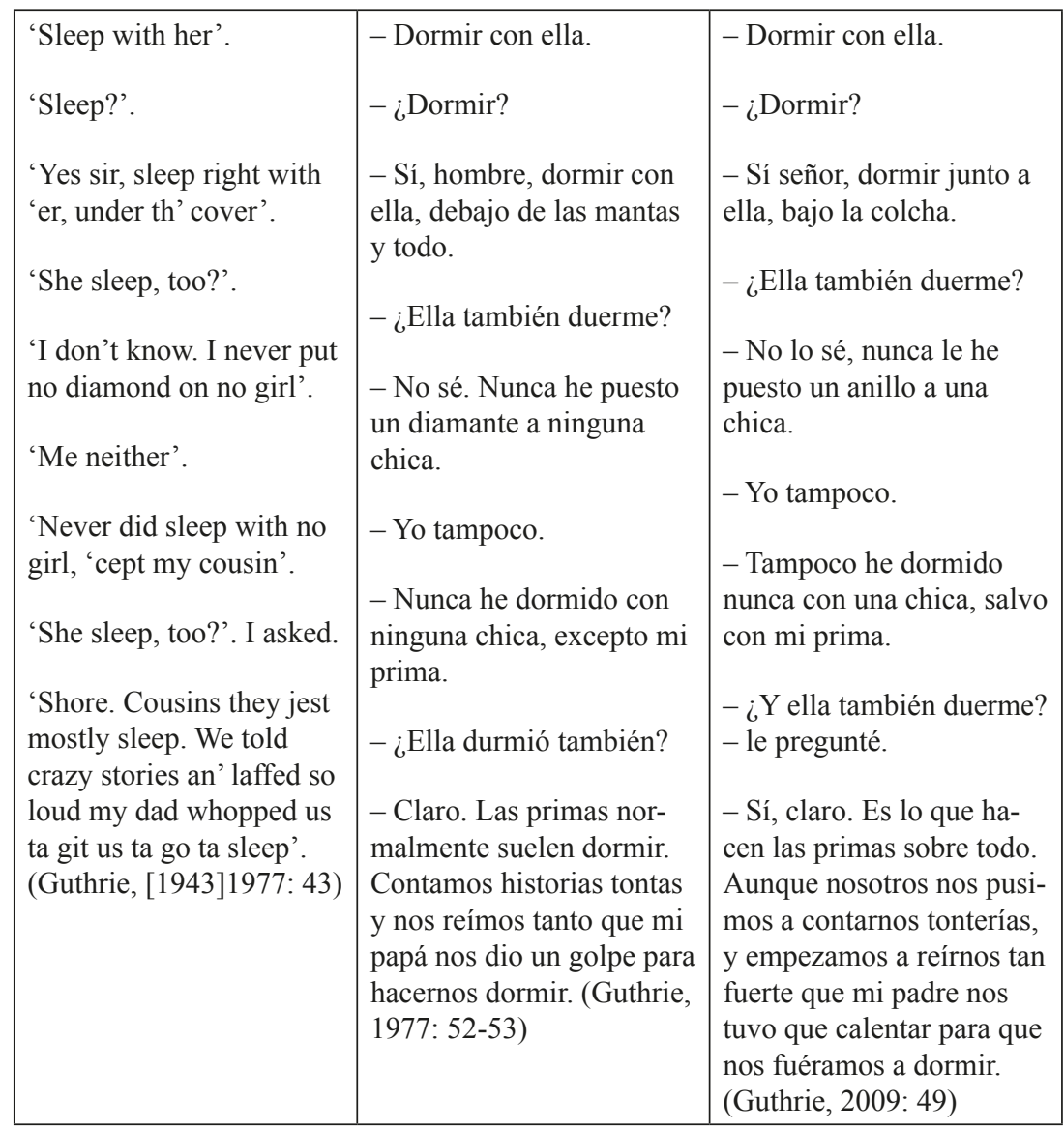

Table 1. Sexual morals and religion: source text and translations

No matter how innocent both kids may be, there is no doubt that the topic of their conversation can be said to question the sexual moral standards of the Francoist period. This dialogue includes a highly problematic passage when the other kid tells Woody that he has never slept with a girl, except for his cousin. Although it may sound harmless to modern readers, the slightest mention of any kind of incestuous situation would surely have been elided by Francoist censors. However, neither of the two boys' interventions disappeared in either translation. 


\subsection{Political beliefs}

The continuous references to the socio-political context and Guthrie's reflections on this point have been rendered quite faithfully in both translations. Some extracts from different parts of the book are good examples of this:

\begin{tabular}{|c|c|c|}
\hline $\begin{array}{l}\text { 'I had a brother in Pearl } \\
\text { Harbor! I'm on my way } \\
\text { right this minute to Chi- } \\
\text { cago to go to work rollin' } \\
\text { steel to lick this Hitler } \\
\text { bunch! [...] (Guthrie, } \\
[1943] 1977: 23)\end{array}$ & $\begin{array}{l}\text { - ¡Tuve un hermano en } \\
\text { Pearl Harbor! ¡Me dirijo } \\
\text { ahora mismo a Chicago, } \\
\text { para trabajar en una fábri- } \\
\text { ca de hierro, y dar una pa- } \\
\text { liza a Hitler y a su grupo! } \\
\text { [...] (Guthrie, 1977: 21) }\end{array}$ & $\begin{array}{l}\text { ¡Tenía un hermano en } \\
\text { Pearl Harbor! Ahora voy } \\
\text { a Chicago, voy a laminar } \\
\text { acero para atizarle a la } \\
\text { pandilla del Hitler ése. } \\
\text { [...] (Guthrie, 2009: 83- } \\
\text { 24) }\end{array}$ \\
\hline $\begin{array}{l}\text { 'I dunno what politics is. } \\
\text { Just a good way ta make } \\
\text { some money. [...] Yore } \\
\text { dad likes lots of Money. } \\
\text { So he got some people } \\
\text { ta vote fer 'im, so then } \\
\text { he got 'im two guns an' } \\
\text { went around c'lectin' } \\
\text { money. [...] (Guthrie, } \\
[1943] 1977: 72)\end{array}$ & $\begin{array}{l}\text { - No sé lo que es la políti- } \\
\text { ca. Solo una buena manera } \\
\text { de ganar dinero. [...] A } \\
\text { tu papá le gusta ganar } \\
\text { mucho dinero. Entonces } \\
\text { hizo votar por él a algunas } \\
\text { personas, y cogió dos } \\
\text { revólveres y fue recogien- } \\
\text { do dinero. [...] (Guthrie, } \\
\text { 1977: 98) }\end{array}$ & $\begin{array}{l}\text { - No sé muy bien qué es } \\
\text { la política. Solo que es } \\
\text { un buen modo de hacer } \\
\text { algo de dinero. [...] A tu } \\
\text { padre le gusta ir sobrado } \\
\text { de dinero. Así que tiene a } \\
\text { gente que lo vota, y tiene } \\
\text { dos pistolas y va por ahí } \\
\text { recaudando dinero. [...] } \\
\text { (Guthrie, 2009: } 83-84)\end{array}$ \\
\hline $\begin{array}{l}\text { 'If ever single livin' one } \\
\text { of 'em would all git to- } \\
\text { gether an' git rid of them } \\
\text { ol' mean, bad politics, } \\
\text { they'd all feel lots bet- } \\
\text { ter, an' wouldn't fight } \\
\text { each other so much, an' } \\
\text { that'd make my mama } \\
\text { fell better'. (Guthrie, } \\
\text { [1943]1977: } 73 \text { ) }\end{array}$ & $\begin{array}{l}\text { - Si todos ellos se reunie- } \\
\text { sen y sacasen esa política } \\
\text { tan mala, se sentirían } \\
\text { mucho mejor, y no se } \\
\text { pelearían tanto, y eso haría } \\
\text { sentirse mejor a mi mamá. } \\
\text { (Guthrie, 1977: 98) }\end{array}$ & $\begin{array}{l}\text { - Si todas las personas se } \\
\text { juntan y mandan a freír } \\
\text { espárragos a esa mala y } \\
\text { traidora de la política, se } \\
\text { sentirán mucho mejor y no } \\
\text { se pelearán tanto, y enton- } \\
\text { ces mi madre estará mejor. } \\
\text { (Guthrie, 2009: } 84 \text { ) }\end{array}$ \\
\hline
\end{tabular}




\begin{tabular}{|c|c|c|}
\hline $\begin{array}{l}\text { 'Men! Hey! Listen! I } \\
\text { know we all see this same } \\
\text { thing - like news reels in } \\
\text { our mind. Alla th' work } \\
\text { that needs ta be done - } \\
\text { better highways, better } \\
\text { buildin's, better houses. } \\
\text { Ever'thing needs ta be } \\
\text { fixed up better! But, God- } \\
\text { damit, I ain't no master } \\
\text { mind! All I know is we } \\
\text { gotta git together an' stick } \\
\text { together! This country } \\
\text { won't ever git much bet- } \\
\text { ter as long as it's dog eat } \\
\text { dog, ever' man fer his } \\
\text { own self, an' ta hell with } \\
\text { th' rest of th' world. We } \\
\text { gotta all git together, dam } \\
\text { it all, an' make somebody } \\
\text { give us a job somewhere } \\
\text { doin' somethin'!' (Guth- } \\
\text { rie, [1943] 1977: 186- } \\
187 \text { ) }\end{array}$ & $\begin{array}{l}\text { - ¡Eh, vosotros! ¡Escu- } \\
\text { chad! ¡Yo sé que todos } \\
\text { vemos lo mismo, como si } \\
\text { fuera el "No-Do” en nues- } \\
\text { tra mente! Todo el trabajo } \\
\text { que hay que hacer, me- } \\
\text { jores carreteras, mejores } \\
\text { edificios, mejores casas. } \\
\text { ¡Todo tiene que arreglarse } \\
\text { mejor! ¡Pero yo no soy } \\
\text { un genio! ¡Todo lo que sé } \\
\text { es que debemos unirnos } \\
\text { y permanecer unidos! } \\
\text { Este país no va a mejorar } \\
\text { nunca mientras continúe } \\
\text { esta merienda de negros, } \\
\text { este sálvese quien pueda y } \\
\text { al infierno con los demás. } \\
\text { ¡Tenemos que unirnos, } \\
\text { coño, y obligar a alguien a } \\
\text { darnos un trabajo en algún } \\
\text { lado, haciendo cualquier } \\
\text { cosa! (Guthrie, 1977: } \\
269-270 \text { ) }\end{array}$ & $\begin{array}{l}\text { - ¡Amigos! ¡Eh! ¡Escu- } \\
\text { chad! Sé que todos vemos } \\
\text { las cosas igual... como si } \\
\text { pasaran un noticiario en } \\
\text { nuestra cabeza. Todo el } \\
\text { trabajo que ha de hacerse: } \\
\text { mejores carreteras, me- } \\
\text { jores edificios, mejores } \\
\text { casas. ¡Todo anda falto } \\
\text { de un buen arreglo! Pero, } \\
\text { maldita sea, ¡yo no soy } \\
\text { ningún cabecilla! ¡Lo úni- } \\
\text { co que sé es que debemos } \\
\text { juntarnos y mantenernos } \\
\text { unidos! Este país no lo- } \\
\text { grará recuperarse mientras } \\
\text { sigamos con el todos con- } \\
\text { tra todos, cada uno bus- } \\
\text { cando su propio beneficio } \\
\text { y al diablo con el resto } \\
\text { del mundo. ¡Tenemos que } \\
\text { unirnos todos, maldita sea, } \\
\text { y conseguir que alguien } \\
\text { en alguna parte nos dé un } \\
\text { empleo para hacer lo que } \\
\text { sea! (Guthrie, 2009: } 215 \text { ) }\end{array}$ \\
\hline $\begin{array}{l}\text { Lord, it's stormy on that } \\
\text { ocean / Windy on th' } \\
\text { deep blue sea / Boys, it's } \\
\text { stormy on the ocean / } \\
\text { Windy on th' deep blue } \\
\text { sea / I'm gonna bake } \\
\text { them Nazis a chicken } \\
\text { / Loaded full of TNT! } \\
\text { (Guthrie, [1943] 1977: } \\
\text { 258) }\end{array}$ & $\begin{array}{l}\text { Señor, hay tormenta en } \\
\text { este océano / Viento sobre } \\
\text { el mar profundo / Chicos, } \\
\text { hay tormenta en el océano } \\
\text { / Viento sobre el mar azul } \\
\text { / Voy a cocinar un pollo } \\
\text { para esos nazis / iRelleno } \\
\text { de TNT! (Guthrie, 1977: } \\
\text { 380) }\end{array}$ & $\begin{array}{l}\text { Señor; hay tormenta en el } \\
\text { océano / y sopla el viento } \\
\text { en el hondo mar azul. / } \\
\text { Chicos, hay tormenta en el } \\
\text { océano / y sopla el viento } \\
\text { en el hondo mar azul. / } \\
\text { iA los nazis les asaré un } \\
\text { pollo / bien relleno de } \\
\text { dinamita! (Guthrie, 2009: } \\
\text { 296) }\end{array}$ \\
\hline
\end{tabular}

Table 2. Political beliefs: source text and translations

In spite of the fact that Guthrie disagrees with Francoist principles, the examples quoted above confirm that they have been rendered in both translations, raising readers" awareness and generating a "we shall overcome" spirit and urge for improvement which still remains relevant in today's world. 


\subsection{The use of indecorous language}

The use of indecorous language in narrative greatly contributes to character portrayal. Chapter One, "Soldiers in the Dust", is a good example of this. It recounts a journey in a train full of hoboes, where Guthrie "could see men of all colors bouncing along in the boxcar" (Guthrie, [1943] 1977: 15). The following are some of the insults that could be heard during that journey:

\begin{tabular}{|c|c|c|}
\hline $\begin{array}{l}\text { 'Hey! You old bastard! } \\
\text { Quit bustin' up our } \\
\text { card game!' (Guthrie, } \\
\text { [1943]1977: 18) }\end{array}$ & $\begin{array}{l}\text { - ¡Oye! ¡Viejo imbécil! } \\
\text { ¡Estás interrumpiendo } \\
\text { nuestro juego! (Guthrie, } \\
\text { 1977: 15) }\end{array}$ & $\begin{array}{l}\text { - ¡Eh, tú, viejo cabrón! } \\
\text { ¡Deja de reventarnos la } \\
\text { partida! (Guthrie, 2009: } \\
\text { 19) }\end{array}$ \\
\hline $\begin{array}{l}\text { 'Say, stud! Who daya } \\
\text { t'ink youse are? [...]' } \\
\text { (Guthrie, [1943]1977: 19) }\end{array}$ & $\begin{array}{l}\text { - ¡Oye, tú, macho! ¿Quién } \\
\text { te mete a ti en esto? } \\
\text { (Guthrie, 1977: } 15 \text { ) }\end{array}$ & $\begin{array}{l}\text { - ¡Oye, machote! ¿Quién } \\
\text { te crees que eres? } \\
\text { (Guthrie, 2009: 19) }\end{array}$ \\
\hline $\begin{array}{l}\text { 'Keep outta dis! Stepin- } \\
\text { fetchit!' (Guthrie, [1943] } \\
\text { 1977: 19) }\end{array}$ & $\begin{array}{l}\text { - ¡A ti que te importa! } \\
\text { ¡Mono negro! (Guthrie, } \\
\text { 1977: 16) }\end{array}$ & $\begin{array}{l}\text { - ¡Tú no te metas, Ste- } \\
\text { pinfechit!* [...] Era el } \\
\text { nombre artístico del actor } \\
\text { negro Lincoln Perry, que } \\
\text { interpretaba a un perso- } \\
\text { naje holgazán, torpón y } \\
\text { alegremente necio con- } \\
\text { siderado ya en los años } \\
\text { cuarenta como un este- } \\
\text { reotipo degradante }(\mathrm{N} \text {. del } \\
\text { T.). (Guthrie, 2009: } 20)\end{array}$ \\
\hline $\begin{array}{l}\text { 'You're a lyin' skunk!' } \\
\text { (Guthrie, [1943] 1977: } \\
\text { 22) }\end{array}$ & $\begin{array}{l}\text { - ¡Mentira! (Guthrie, } \\
\text { 1977: 19) }\end{array}$ & $\begin{array}{l}\text { - ¡Mofeta embustera! } \\
\text { (Guthrie, 2009: 23) }\end{array}$ \\
\hline
\end{tabular}

Table 3. Indecorous language: source text and translations

These examples demonstrate that some of the insults disappeared in the 1977 translation. However, sometimes their elision has been overcompensated, as can be observed in the third example, where "Stepinfetchit!" becomes "¡Mono negro!”. As a result, although most of the linguistic markers of dialectal varieties have been standardised (Assis Rosa, 2012), the selected extracts prove that character portrayal has been quite successfully rendered and that the directness and richness of Guthrie's style can be easily recognised in both translations. 


\section{Bound for Glory in post-Francoist and modern-day Spain}

Guthrie's work has had a significant impact not only on the social and cultural context of America but also on the collective memory of many other countries. The presence of his work in post-Francoist and modern Spain alike seems to corroborate that he has been and still is considered one of the spiritual leaders of countercultural circles in our country. In fact, taking into account that "El contracultural de antes es el antisistema de ahora, aunque se haya incrementado la pobreza y la confusión ideológica" (Viñuela, 2012: 8), Guthrie seems to have been rediscovered as the idol of the disadvantaged in the 21 st century.

The key role played by Star Books and Global Rhythm Press in post-Francoist and modern culture allowed Spanish readers to have access to the two existing translations of Guthrie's autobiography in Spain at two very different points in time. It seems that the relevant sociopolitical changes that have taken place in Spain during the past 30 years have helped witness the difference in the design of the 1977 and the 2009 book covers. While 1977 was still too close to a political regime which not so long before condemned all sorts of divergent political and cultural expressions, 30 years later Global Rhythm sent a clear political message in a more explicit front cover which included the famous photograph of Guthrie with the legendary inscription "This machine kills fascist" on the guitar of the folksinger.

Contrary to other studies which show that, instead of being restored, translations of foreign fiction originally translated and censored during Franco's period tend to keep their censored passages in subsequent editions (Gómez Castro, 2008), our descriptive-comparative analysis has demonstrated that in the case of Bound for Glory no trace of Francoist censorship can be found in any of the most problematic passages of the 1977 Spanish translation. As can be observed in the examples in section 4 of this paper, the problematic references which impregnate the source text in general have been successfully rendered in both translations. This evidence makes us think that, since it was never translated during the Francoist period, the fact that it never had to suffer the effects of Francoist censorship may have favoured the publication in 1977 of the uncensored translation. Taking into account the absence of censorship in the first translation, there has been no need to restore any censored passages in the more modern 2009 re- 
translation, whose main interest lays, then, in the fact that it is more idiomatic for current readers.

It is our opinion that similar studies to the one presented in these pages should be carried out in the future to corroborate whether the case of Bound for Glory is an exception to the general norm or, on the contrary, whether highly controversial foreign books which never crossed the Spanish borders until the post-Francoist period no longer had to suffer the effects of censorship.

\section{Bibliography}

Abellán, Manuel Luis. 1980. Censura y creación literaria en España (19391976). Barcelona: Península.

Anon. 2014 (11 March). El folk fue una contracultura. emol. http://www. emol.com/noticias/magazine/2014/03/11/649102/el-folk-fue-unacontracultura.html [Accessed 02/01/2015].

Ashby, Hal (director) \& Getchell, Robert (screenplay). (1976). Bound for Glory. [DVD]. Madrid: Twentieth Century Fox Home Entertainment. ES. S.A.

Assis Rosa, Alexandra. 2012. Translating Place: Linguistic Variation in Translation. Word and Text II (2): 75-97.

Beaugrande, Robert-Alain de \& Dressler, Wolfgang U. 1981. Introduction to Text Linguistics. London: Longman.

Castillo, Encarna. 2014 (02 December). Star. La contracultura de los 70 - Juan José Fernández - Reseña. 13 millones de naves. http://www.13millonesdenaves.com/comics.php?idcomic=83 [Accessed 02/01/2015].

Dirección General de Cultura Popular. 1977. Con destino a la gloria (Unpublished File No. 3503-77). Madrid: Ministerio de Información y Turismo.

Dylan, Bob. 1984. Writings and Drawings. London: Granada.

Marsh, Dave \& Leventhal, Harold (ed.). 1992. Pastures of Plenty. A self-portrait. The unpublished writings of an American folk hero: Woody Guthrie. New York: Harper Perennial.

Fernández, Juan José. 2007. Star: la contracultura de los 70. Barcelona: Glenat.

Fernández Ferrer, Antonio. 2007. La Canción Folk Norteamericana. Granada: Universidad de Granada.

Global Rhythm. 2011. Global Rhythm Press. http://www.globalrhythmpress. com/es [Accessed 02/01/2015]. 
Gómez Castro, Cristina. 2008. The Fancoist Censorship Casts a Long Shadow: Translations from the Period of the Dictatorship on Sale Nowadays. In Seruya, Teresa \& Lin Moniz, Maria (ed.) Translation and Censorship in Different Times and Landscapes. Newcastle: Cambridge Scholars Publishing, 184-195.

Gonzalo, Jaime. 2009, 2011, 2014. Poder Freak. Una crónica de la contracultura (3 vol.). Leioa: Libros Crudos.

Greenway, John. 1953. American Folk-Songs of Protest. Philadelphia: Univ. of Pennsylvania Press.

Guthrie, Green. 2014. Guthrie Green. https://www.guthriegreen.com/ [Accessed 02/01/2015].

Klein, Joe. [1980] 1998. Woody Guthrie: A Life. London: Faber and Faber.

Manrique, Diego A. 2008 (07 March). Un milagro llamado "Star". El País. http://elpais.com/diario/2008/03/07/tentaciones/1204917773_850215. html [Accessed 02/01/2015].

Neubert, Albrecht \& Shreve, Gregory M. 1992. Translation as Text. Kent: The Kent State University Press.

Nord, Christiane. 1997. Translating as a Purposeful Activity: Functionalist Approaches Explained. New York: Routledge.

Ribas, José. 2007. Los 70 a destajo: Ajoblanco y libertad. Barcelona: RBA Libros.

Scaduto, Anthony. 1973. Bob Dylan. London: Abacus.

Shelton, Robert. 1987. No direction home. The life and music of Bob Dylan. London: Penguin.

Toury, Gideon. [1995] 2012. Descriptive Translation Studies and Beyond. Amsterdam/Philadelphia: John Benjamins.

Tymoczko, Maria. 2002. Connecting the Two Infinite Orders. Research Methods in Translation Studies. In Hermans, Theo (ed.) Crosscultural Transgressions. Research Models in Translation Studies II. Historical and Ideological Issues. Manchester: St. Jerome Publishing, 9-25

Van Doren, Charles \& McHenry, Robert (ed.). 1971. Webster's Guide to American History. Massachusetts: G. \& C. Merrian Company.

Viñuela, Enrique. 2012 (03 April). La revolución como mercancía. Pérgola. http://www.libroscrudos.com/wp-content/uploads/2012/04/201204-03-Periodico-Bilbao.pdf [Accessed 02/01/2015].

Wiley Hitchcock, Hugh. 1988. Music in the United States: A Historical Introduction. New Jersey: Prentice Hall.

Woody Guthrie Publications, Inc. 2001-2015. Official Woody Guthrie Website. http://www.woodyguthrie.org/ [Accessed 02/01/2015].

Woody Guthrie Folk Festival. 2013. Woody Guthrie Folk Festival. http://www. woodyguthrie.com/ [Accessed 02/01/2015]. 
Woody Guthrie Center. 2013-2015. Woody Guthrie Center. http://woodyguthriecenter.org/ [Accessed 02/01/2015].

\section{List of texts}

Guthrie, Woody. [1943] 1977. Bound for Glory. London: Picador.

Guthrie, Woody. 1977. Con destino a la gloria. Barcelona: Producciones Editoriales S. A. Star Books. [Tr. Lisa Garrigues \& Alberto Estival].

Guthrie, Woody. 2009. Rumbo a la gloria. Barcelona: Global Rhythm Press

S. L. Memorias. [Tr. Ezequiel Martínez]. 